BRIEF COMMUNICATION

\title{
DEVELOPMENT OF 5-DAY RABBIT BLASTOCYSTS AFTER CULTURE AT $37^{\circ} \mathrm{C}$
}

\author{
R. E. STAPLES \\ Worcester Foundation for Experimental Biology, \\ Shrewesbury, Massachusetts, U.S.A.
}

(Received 17th November 1966)

\begin{abstract}
Summary. Rabbit blastocysts were cultured in vitro at $37^{\circ} \mathrm{C}$ for 8,16 or $24 \mathrm{hr}$ in modified $\mathrm{F}_{10}$ medium. Subsequent transfer to suitable recipient does revealed that blastocyst viability was maintained in vitro for at least $16 \mathrm{hr}$. The percentage of viable foetuses developing from blastocycts cultured for at least $8 \mathrm{hr}$ was equal to that from non-cultured blastocysts.
\end{abstract}

The rabbit ovum readily cleaves to the late morula or early blastocysts stage upon culture, but difficulty has been experienced in obtaining further development in vitro. The cultured zygotes remain viable and come to term if transferred into host uteri. Expanded blastocysts have been cultured in vitro at approximately $37^{\circ} \mathrm{C}$ with some success (Brachet, 1912; Waterman, 1932; Pincus \& Werthessen, 1938; Chang, 1950; Lutwak-Mann, Hay \& Adams, 1962), but their successful development following transfer has not been reported.

However, 5-day rabbit blastocysts will increase in size (Daniel, 1965) when cultured at $37^{\circ} \mathrm{C}$ in a modification of the cell culture medium $F_{10}$ of $\mathrm{Ham}$ (1963). The increase occurred after both 4 and $24 \mathrm{hr}$ in modified $F_{10}$ alone, but added serum was required to match the size range attained in vivo. The purpose of this investigation was to culture such blastocysts in vitro at $37^{\circ} \mathrm{C}$, in the modified $F_{10}$ medium with and without serum added, and to test the capacity of the cultured blastocysts to develop into normal foetuses.

Mature, Dutch-Belted does weighing more than $1.75 \mathrm{~kg}$ were used (Staples \& Holtkamp, 1966). One hundred and eleven virgin does were utilized as blastocyst donors: fifty-eight post-partum does served as recipients of control and cultured blastocysts.

Donor females received an ovulating dose of luteinizing hormone (LH) and were artificially inseminated with semen from a fertile, Dutch-Belted buck (Foote, Hafs, Staples, Gregoire \& Bratton, 1963). Those donors yielding blastocysts to be cultured were killed by cervical dislocation $120 \mathrm{hr}$ after LH injection; those yielding blastocysts for control transfers were killed following the culture period, shortly before transfer. 
The basic medium was $F_{10}$, as modified by Daniel (1965), purchased from the Colorado Serum Co., Denver, Colorado. For some of this work rabbit serum was added to constitute either $5 \%$ or $10 \%$ of the final medium used. The blood used for serum preparation was taken by heart puncture from rabbits on the 5th day of pregnancy and was sterilized by millipore filtration before storage at $-15^{\circ} \mathrm{C}$. If serum was not included in the medium the blastocysts used were rinsed with some of the medium before culture to eliminate as much carry-over of fluid and debris from the uteri as possible. Except for some of the first $24-\mathrm{hr}$ cultures, penicillin (100 units $/ \mathrm{ml}$ of medium) and streptomycin (50 $\mu \mathrm{g} / \mathrm{ml}$ of medium) were routinely added immediately before culture, in $0.1 \mathrm{ml}$ of saline $/ 20 \mathrm{ml}$ of culture medium.

The 5-day blastocysts were flushed through the cervices with $2 \mathrm{ml}$ of medium, counted and measured by means of a stereoscopic microscope fitted with an ocular micrometer. For culture at $37^{\circ} \mathrm{C}$ the blastocysts were retained in $1.5 \times 4.5$ $\mathrm{mm}$ vials containing $1 \mathrm{ml}$ of medium. Before putting on the screw-cap each vial was gassed with $\mathrm{CO}_{2}$ :air mixture $(5: 95)$. Each vial was then put into a lighttight $2.5 \times 6.0 \mathrm{~mm}$ screw-capped bottle, which was similarly gassed, and finally sealed with masking tape. About 20 min elapsed between the death of a donor and the start of the culture period. Just before the end of the predetermined culture period, the recipients were anaesthetized with pentobarbital sodium (P.B.S., Bioceutic Laboratories) and laparotomized. It was verified by inspection of the ovaries that ovulation had taken place and corpora lutea were present. Control blastocysts were obtained and handled utilizing the procedure described above. The blastocycts were removed from culture, measured and transferred to the left uterine horn of the recipient; the control blastocysts were transferred to the right uterine horn of the same recipient. Blastocysts were handled in sterilized capillary tubes and transferred with minimal transfer of fluids by slow ejection into the uterine lumen through a stab wound in the uterine wall near the ovarian end. No more than five blastocysts were transferred to a single horn.

On Day 12 of gestation all recipients were laparotomized and the number, size, position and appearance of implantation sites were recorded. The recipients were subsequently killed by cervical dislocation on Day 27 , and the viability, number, position and weight of foetuses were noted and each was inspected for the presence of gross malformations. All were anaesthetized, fixed in $70 \%$ ethanol, and processed for skeletal examination (Staples \& Schnell, 1964).

Blastocycts were initially cultured at $37^{\circ} \mathrm{C}$ for $24 \mathrm{hr}$. During culture without serum, many blastocycts collapsed $(52 / 145)$ but upon addition of $5 \%$ serum significantly fewer $(P<0 \cdot 01)$ collapsed $(10 / 61)$. The non-collapsed blastocysts appeared normal under the dissecting microscope, in that the surface cellular arrangement appeared to be uniform, but the diameters of these blastocysts were only $1.64 \mathrm{~mm} \pm 0.05$ upon culture without serum, and $1.69 \mathrm{~mm} \pm 0.08$ with serum included against $3.41 \mathrm{~mm} \pm 0.05$ among 142 control blastocysts. Fiftyeight of these intact blastocysts were then transferred to pseudopregnant does, but viable foetuses were not obtained at autopsy on Day 27 of gestation. In fact, only five implantation sites were observed upon laparotomy on Day 12 and the diameter of these was about one-fourth the normal size. 
In view of this negative response, blastocysts were next cultured for $8 \mathrm{hr}$. The addition of serum was found necessary to prevent blastocyst collapse $(0 / 64$ against 17/49) and to obtain an increase in size comparable to that obtained in vivo (Table 1). Blastocyst viability (Table 2 ) did not appear to be adversely affected by culture at $37^{\circ} \mathrm{C}$ for $8 \mathrm{hr}$ provided serum was added to the modified $\mathrm{F}_{10}$ medium.

Following culture for $16 \mathrm{hr}$, a few blastocycts collapsed (6/64) in spite of the presence of serum and although the blastocysts continued to increase in size, they did so at slightly less than the normal rate in vivo (Table 1). It is noteworthy, however, that seven live young were recovered on Day 27, following transfer of twenty-five blastocysts that had been cultured in vitro for $16 \mathrm{hr}$. Percentage viability was less than in controls, but was not significantly different $(0 \cdot 10<P<0 \cdot 20)$ from that obtained after $8 \mathrm{hr}$ of culture.

TABLE 1

BLASTOCYST SIZE BEFORE AND AFTER GULTURE AT $37^{\circ}$ G IN MODIFIED $F_{10}$ MEDIUM*

\begin{tabular}{|c|c|c|c|c|c|c|}
\hline \multirow{2}{*}{$\begin{array}{l}\text { Hours of } \\
\text { cullure }\end{array}$} & \multirow[b]{2}{*}{ Medium } & \multicolumn{3}{|c|}{ Cultured blastocysts } & \multicolumn{2}{|c|}{ Control blastocysts } \\
\hline & & No. & $\begin{array}{c}\text { Initial } \\
(m m \pm S E)\end{array}$ & $\begin{array}{c}\text { Final } \\
(m m \pm S E)\end{array}$ & No. & $\begin{array}{c}\text { Size } \\
(m m \pm S E)\end{array}$ \\
\hline 8 & $\begin{array}{l}\text { No serum } \\
\text { Serum }(10 \%)\end{array}$ & $\begin{array}{l}49 \\
64\end{array}$ & $\begin{array}{l}1 \cdot 15 \pm 0.05 \\
1.37 \pm 0.03\end{array}$ & $\begin{array}{l}1.28 \pm 0.05 \\
1.62 \pm 0.05\end{array}$ & 69 & $1 \cdot 50 \pm 0 \cdot 05$ \\
\hline 16 & Serum $(10 \%)$ & 64 & $1.35 \pm 0.03$ & $1.92 \pm 0.07$ & 29 & $2 \cdot 42 \pm 0 \cdot 10$ \\
\hline
\end{tabular}

* Only intact blastocysts included.

TABLE 2

VIABILITY OF GULTURED BLASTOCYSTS UPON TRANSFER TO PSEUDOPREGNANT DOES*

\begin{tabular}{c|l|c|c|c|c}
\hline $\begin{array}{c}\text { Hours of } \\
\text { culture }\end{array}$ & Medium & $\begin{array}{c}\text { No. } \\
\text { blastocysts } \\
\text { transferred }\end{array}$ & $\begin{array}{c}\% \text { Blastocysts } \\
\text { resulting } \\
\text { in implants } \\
\text { (Day 13) }\end{array}$ & $\begin{array}{c}\% \text { Blastocysts } \\
\text { resulting } \\
\text { in live foetuses } \\
\text { (Day 27) }\end{array}$ & $\begin{array}{c}\text { No. recipients } \\
\text { with live young } \\
\text { /group }\end{array}$ \\
\hline 8 & No serum & 15 & $46 \cdot 7$ & $6 \cdot 7$ & $1 / 4$ \\
& Serum (10\%) & 25 & $52 \cdot 0$ & 40.0 & $5 / 5$ \\
16 & Control & 55 & $63 \cdot 6$ & $49 \cdot 1$ & $11 / 14$ \\
& Serum (10\%) & 25 & $60 \cdot 0$ & $28 \cdot 0$ & $3 / 5$ \\
\hline
\end{tabular}

* Only intact blastocysts transferred.

Table 2 included all results obtained following transfer of non-cultured blastocysts but results from cultured blastocysts were included only from those does with at least one viable foetus on the control side, the argument being that if control blastocysts failed to survive in a given doe, the experimental or cultured blastocysts in the contralateral horn could not be expected to do so, and, if the cultured blastocysts did not develop either, failure could not be attributed solely to the effects of culture. In fact, cultured blastocysts never survived if control blastocysts failed in the contralateral horn. If the data on all cultured blastocysts are included, regardless of the result in the contralateral 
control horn, then after an $8 \mathrm{hr}$ culture period with serum, 11/50 blastocysts developed to Day 27 compared with $1 / 25$ in the absence of serum. The results after $16 \mathrm{hr}$ of culture remain unchanged.

On gross examination of the young obtained on Day 27 of gestation as well as examination of the cleared skeletons, all appeared to be normal.

Gratitude is extended to Miss Mary Jane Hepinstall for excellent technical assistance. Supported by PHS Grant No. HD 01785 and the National Foundation.

\section{REFERENCES}

Brachet, A. (1912) Développement in vitro de blastodermes et de jeunes embryons de mammifères. C.r. hebd. Séanc. Acad. Sci. 55, 119.

Chang, M. G. (1950) Transplantation of rabbit blastocysts at late stage: probability of normal development and viability at low temperature. Science, 111, 544 .

Daniel, J. C., JR. (1965) Studies on the growth of 5-day-old rabbit blastocysts in vitro. F. Embryol. exp. Morph. 13, 83.

Foote, R. H., Hafs, H. D., Staples, R. E., Gregorre, A. T. \& Bratton, R. W. (1963) Ovulation rates and litter sizes in sexually receptive and nonreceptive artificially inseminated rabbits given varying dosages of luteinizing hormone. F. Reprod. Fert. 5, 59.

HaM, R. G. (1963) An improved nutrient solution for diploid Chinese hamster and human cell lines. Expl Cell Res. 29, 515.

Lutwak-Mann, C., Hay, M. F. \& Adams, C. E. (1962) The effect of ovariectomy on rabbit blastocysts. 7. Endocr. 24, 185.

Pincus, G. \& Werthessen, N. T. (1938) The comparative behaviour of mammalian eggs in vivo and in vitro. III. Factors controlling the growth of the rabbit blastocyst. 7. exp. Zool. 78, 1.

Staples, R. E. \& HoltKamp, D. E. (1966) Influence of body weight upon corpus luteum formation and maintenance of pregnancy in the rabbit. 7. Reprod. Fert. 12, 221.

Staples, R. E. \& Schneld, V. L. (1964) Refinements in rapid clearing in the KOH-alizarin red S method for fetal bone. Stain Technol. 39, 62.

Waterman, A. J. (1932) Culture in vitro and transplantation of young rabbit embryos. Anat. Rec. 54, 72, Abstract No. 116. 